\title{
Deciphering the impact of novel coronavirus pandemic on agricultural sustainability, food security, and socio-economic sectors-a review
}

\author{
Mehvish Mumtaz ${ }^{1} \cdot$ Nazim Hussain $^{1} \cdot$ Zulqarnain Baqar $^{1} \cdot$ Saima Anwar $^{2} \cdot$ Muhammad Bilal $^{3}$ (D) \\ Received: 31 May 2021 / Accepted: 26 July 2021 \\ (C) The Author(s), under exclusive licence to Springer-Verlag GmbH Germany, part of Springer Nature 2021
}

\begin{abstract}
The Spanish flu, Asian flu, Hong Kong flu, HIV/AIDS, SARS, Ebola, and Swine flu, among others, have had a significant impact on agriculture, education, the economy, and human activities, including leisureliness, shipping, healthiness, fisheries, mining, industry, and trade. Currently, manhood is dealing with a new epidemic, the infection of the latest coronavirus (2019-nCoV), which causes a deadly disease named COVID-19. This article aims to examine COVID-19's effect on agriculture, education, and the economy. There are existing estimates to conclude that the COVID-19 pandemic has a significant influence on agriculture and the food supply chain, mostly influencing food demand and, as a result, food security, with a disproportionate impact on the most disadvantaged. To overcome spread of COVID-19, a non-contact food delivery system has been used by utilizing drown for this purpose. This epidemic crisis also introduced a digital education system that is challenging for students and teachers who are not educated in it. Weak infrastructure, such as electricity, poor access to the Internet connection, and a lack of technology literacy, has hampered the online education system. Coronavirus has an undesirable influence on the global economy by affecting tourism, the financial market, commerce, shipping, manufacturing, and the service sector. The exchange market was also down during the COVID-19 pandemic. In conclusion, we should strictly follow SOP's to improve our agriculture, education, economy, and other ways of normal life. We should also be vaccinated to fulfill our all losses in different fields.
\end{abstract}

Keywords Coronavirus $\cdot$ Agriculture $\cdot$ Food supply $\cdot$ Food safety, · Digital education system $\cdot$ Economic impact $\cdot$ Transportation and tourism

\section{Introduction}

COVID-19 is a new illness of the coronavirus. SARS CORONA Virus-2 is an RNA virus that leads to many respiratory problems varying from the common cold to acute diseases such as severe acute respiratory syndrome (SARS) and

Responsible Editor: Philippe Garrigues

Zulqarnain Baqar

zulqarnainzb14@gmail.com

$\triangle$ Muhammad Bilal

bilaluaf@hyit.edu.cn

1 Centre For Applied Molecular Biology (CAMB), University of Punjab, Quaid-e-Azam Campus, Lahore 54800, Pakistan

2 Department of Botany, University of Okara, Okara 56130, Pakistan

3 School of Life Science and Food Engineering, Huaiyin Institute of Technology, Huai'an 223003, China
Middle East respiratory syndrome (MERS). Symptoms of this disease vary with its strains. Its symptoms are fever, coughing, loss of smell, loss of taste, tiredness, diarrhea, headache and difficulty in breathing, loss of speech or movement and pain in the chest, etc. This viral disease is transmitted by touching an infected place or things and through sneezing and coughing droplets from an infected person to an uninfected person within $6 \mathrm{ft}$ between them. The evidence from the outbreak of this viral disease shows that people over 60 years old and those with latent medical conditions (such as cancer and diabetes etc.) are at high risk of this viral disease

SARS-CoV-2 (severe acute respiratory syndrome coronavirus 2) is a new coronavirus discovered in Wuhan, Hubei province, China, in December 2019. SARS-CoV-2 is related to the Coronaviridae family, and it is assumed that it is acquired from bat-like coronavirus. It is transmitted from animal to human and later from human to human by the appearance of nucleocapsid $\mathrm{N}$ protein and spike glycoprotein mutation (Benvenuto et al. 2020). On 6 February 2020, over 31,000 
corona-positive cases were diagnosed, and about 636 deaths were reported in China. This virus gives rise to the spread of viral pneumonia, which is called coronavirus disease (COVID-19). By confirming SARS-CoV-2 cases in Wuhan, Chinese authorities declared a lockdown in this city to control the spread of disease in other cities and countries ( $\mathrm{Lv}$ et al. 2020). Besides this, on 13 April 2020, greater than 1,770,000 cases in 213 different countries have been confirmed (Table 1). This viral infection spread to other states by migrating infected people from China to other countries (Steffens 2020). The World Health Organization (WHO) announced this COVID-19 spread as a Public Health Emergency of International Concern on 30 January 2020 (Team 2020). On 11 March 2020, WHO declared this outbreak a pandemic (W. H. Organization, 2020). The World Health Organization conclude that this zoonotic disease-causing agent (COVID-19) is an organic threat to the human being. The COVID-19 death rate is underneath than SARS and MERS, but its growth period consists of about 14 days, and a lower infectious rate raises the possibility of SARS-COV-2 infection and its outspread (Wu and McGoogan 2020). Scientists from around the world offer real factual information; these are the only experts in the field to rely. Some of them also succeeded in developing the vaccination that we had all hoped for. Although vaccinations began a few days ago, we will not be able to resume our normal lives until at least autumn 2021. Hopefully, we all took something away from this.

To control its spread, governments of various states impose even complete lockdown in their countries, which affects their economy, education, supply chain market, farming, business, food, and many other ways of normal life. The people were

Table 1 COVID-19 cases in the different countries of the world (number of cases until 23 April 2021)

\begin{tabular}{lllll}
\hline Country & Total cases & Total death & Total recovered & Active cases \\
\hline World & $145,463,353$ & $3,088,359$ & $123,756,672$ & $18,618,322$ \\
USA & $32,669,121$ & 584,226 & $25,236,658$ & $6,848,237$ \\
India & $16,263,695$ & 186,928 & $13,648,159$ & $2,428,608$ \\
Brazil & $14,172,139$ & 383,757 & $12,673,785$ & $1,114,597$ \\
France & $5,408,606$ & 102,164 & $4,242,893$ & $1,063,549$ \\
Turkey & $4,501,382$ & 37,329 & $3,909,935$ & 554,118 \\
Italy & $3,920,945$ & 118,357 & $3,330,392$ & 472,196 \\
Spain & $3,456,886$ & 77,496 & $3,156,955$ & 222,435 \\
Iran & $2,358,809$ & 68,746 & $1,850,791$ & 439,272 \\
South Africa & $1,571,348$ & 53,995 & $1,496,756$ & 20,597 \\
Canada & $1,155,834$ & 23,822 & $1,045,244$ & 86,768 \\
Sweden & 938,343 & 13,923 & 759,702 & 164,718 \\
Pakistan & 784,108 & 16,842 & 682,290 & 84,976 \\
UAE & 506,845 & 1,567 & 488,664 & 16,614 \\
Japan & 546,425 & 9,764 & 491,661 & 45,000 \\
\hline
\end{tabular}

asked to lock in their homes. As a quote, "stay home stay safe" became famous with the spread of COVID-19. This viral disease has effects on the economy of many countries, but mainly it influences the financial system of China, the second-largest world economic country (Siddiquei and Khan 2020). COVID-19 is often referred to as the "Black Swan Event," which happens as a surprise incident and is not thought to be normally found. These events are distinguished from their greatest incompatibility and acute effects (Trevino 1986). Every time there is a threat or possibility of evolving the latest contagious illness (Frank MacFarlane Burnet et al. 1972), starting from the Spanish flu of 1918 to AIDS, for which no proper medicines and treatments are available and considered quite incurable (Table 2). Therefore, COVID-19 is an infectious disease that becomes alarming and interrupts normal human life.

Beyond the ancient epidemics that the world has been suffered from, it has been viewed that this alarming situation of COVID-19 and quarantine recommended for its effect on human enterprises and productivity (Hanashima and Tomobe 2012). It also affects food and cultivation activities when a breakout of contagious disease happens. It also causes starvation and famine at a higher rate (Burgui 2020). By forcing all organizations to move to Internet outlets, the pandemic has caused the physical shutdown of companies, sports events, and schools around the world. COVID-19 also imposes many negative effects on the education system. One of the largest effects is that on-campus education is replaced by digital learning. Online education uses the Internet and other essential tools to create educational content, provide training, and administer a curriculum (Fry 2001).

According to Hrastinski (2008), the two modes of online learning, asynchronous and synchronous web-based learning, are heavily contrasted, but teachers, organizations, and universities must have a piece of thorough information about the advantages and shortcomings for online learning to be successful and productive. COVID-19 would almost certainly have a global economic effect unlike anything seen since the Great Depression of the 1930s (He and Harris 2020). As a result, the COVID-19 disease outbreak is likely to be one of the most important environmental developments in recent marketing history, with the ability to have a measurable influence on corporate social responsively CSR, business ethics, and fundamental marketing theory. Because of the pervasive lockout and psychological distancing interventions around the world, the short-term effect of COVID-19 is felt quickly and easily. Regardless of how the disease outbreak ends, it would have long-term fiscal, societal, democratic, and cultural consequences. People infected with the virus should be tested timely to diagnose this disease and to control its further spread. It will help to save their life. If a carrier person is not tested timely, then there are more chances of virus transmission to the other uninfected people (Lippi and Plebani 2020). 
Table 2 Foremost epidemics from 20th era

\begin{tabular}{lllll}
\hline Name & Time period & Type & Mortality rate & References \\
\hline Spanish flu & $1918-1919$ & H1N1 & More than 50M & (Farmer 2019) \\
Asian flu & $1957-1958$ & H2N2 virus & $1.15 \mathrm{M}$ & (Du et al. 2009) \\
Hong Kong flu & $1968-1970$ & H3N2 virus & 700,000 and 1M & (Siche 2020) \\
HIV/AIDS & 1981-present & Virus & 32M (approximate, March 2020) & (Organization, 2013) \\
COVID-19 & 2019-present & COVID-19 & 36,405 (31 March 2020) & (WHO 2020) \\
\hline
\end{tabular}

The test recommended for COVID-19-infected person is PCR, complete blood count (CBC), swelling-associated specification (ESR, CRP, procalcitonin, ferritin), assays exanimating coagulation, and fibrinolysis (PT, D-dimers, Aptt). Because of the virus' possible capacity to acutely damage the number of organs like kidney, liver, heart, and lungs, it is necessary to examine the synthetical factors to assess the practical function of these organs (Wang et al. 2020). The authorities of different countries are trying their best to overcome this viral outbreak. This article aims to describe the influences of Coronavirus disease on agriculture, education, and the economy of the world.

\section{Impact of COVID-19 on the agriculture sector}

In the lack of a cure or appropriate medication to prevent the epidemic from spreading, countries across the world are resorting to non-pharmaceutical initiatives such as public distancing programs and community lockdowns. The effect of preventing employees from working, meeting, and social interaction has had a significant negative impact on economic activity, particularly in the financial and agricultural sectors (Barichello 2020). Nations have also implemented travel bans, border barriers, and export limits on crops. Now lockdowns are ended in many countries gradually according to the pandemic status, but the effects of lockdown can be assessed. The consequences of lockout are wreaking havoc on wage levels, as agricultural stabilization, and conservation service (ASCs) are labor-intensive for seafood, raw meat, and high-value crops. The labor market disruptions caused by immigrant workers' travel constraints are disrupting their ability to cultivate, refine, and sell agricultural products. COVID-19 has had a significant impact on global food international trade. Agricultural products, which make up a large part of the healthy food supply chain, have suffered greatly as a result of labor market problems. Due to economic sanctions, major terminals worldwide are overloaded with containerized cargo that cannot be exported (Hey 2020). On the Food and Agriculture Organization (FAO) report, COVID-19 has a foremost consequence on agriculture in two categories: food supply and demand. These two causes are inextricably connected to agricultural production, placing it in jeopardy $(\mathrm{A}, \mathrm{F}$.
2020). The associations between such components and the influence of COVID-19 can be seen in Figure 1. Because of COVID-19, food security is at risk, and there is no accessibility to nutrition.

The possibility is that the limitations that disturb utility supply and demand have been distressed, with requests having a powerful influence. Furthermore, most nations have declared the agriculture and agro-food industry to be important, exempting it from firm closures and movement restrictions. The pandemic's direct effects on primary agriculture should be minimal in many nations since the disease has little effect on the natural resources that underpin production. However, in the poorest nations, where agricultural production systems are more labor-intensive and have less capacity to resist a big socioeconomic crisis, the virus poses a considerable concern to food security and livelihoods. Food production should be less influenced by the disaster than demand for other products and services because it is a basic requirement. However, the supply framework has shifted dramatically, with a drop in demand from cafes, hotels, and caterers, the closing of outdoor markets, and a spike in demand from stores. Enterprises along the food system are already reacting to demand fluctuations, for example, by altering manufacturing lines and expanding capacity to address bigger stocks, shifting to online platforms and direct delivery to houses, and employing temporary personnel. The measures needed to contain COVID-19; the necessary adjustments within the sector to comply with all of those methods (which may increase prices), with the need to consider better demand for new products influenced as people change their consumption patterns in response to COVID-19, are the biggest challenges for the sector in all but the poorest countries (Pretty et al. 2003). Authorities must address numerous demands in the brief period, including acting to the health emergency, controlling the effects of the economic shock, and maintaining the smooth operation of the food system. While the pandemic offers some immediate problems for the agriculture industry, it also presents a chance to accelerate reforms in the food and agricultural sector in order to strengthen its resilience in the face of a variety of threats, including climate change.

Production and usage have remained nearly constant. Production companies, raw materials, farming equipment and supplies, manufacturing plants, and field and 

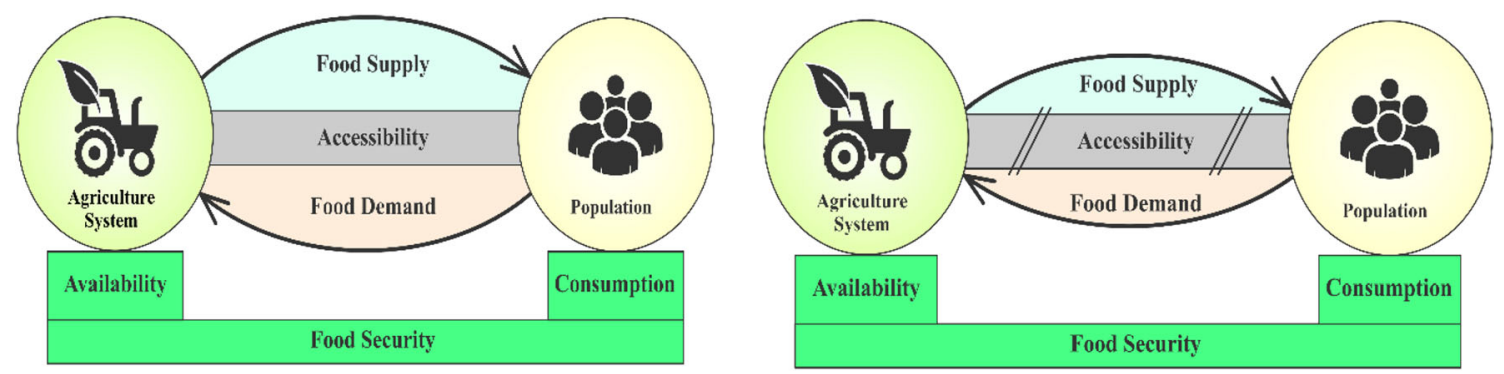

Fig. 1 Method of food preservation (left) without COVID-19 and (right) with COVID-19

manufactured food are part of the agricultural system. People and a variety of marketing systems are both parts of consumption. Despite possessing the most advanced technical resources at their disposal, supply chain organizations around the world are experiencing a crisis in dealing with COVID-19 because they have never seen anything like it before. In this unclear situation, supply chain analysts and clinicians need to gain in-depth expertise in measuring the latest effects of the COVID-19 epidemic on ASCs. In this way, the COVID-19 has affected food supply and demand and exerts a negative influence on the economy of laborers working in farming sectors.

\section{Influence of coronavirus on food supply}

Many nations have undertaken lockdown steps at various periods to minimize the spread of the pandemic (Pan et al. 2020; Peak et al. 2017; Prem et al. 2020). Closing schools, colleges, clubs, and some other public places, restricting movement and public meetings, and even closing industries and enterprises and remaining at home were among the lockdown tactics chosen. At various levels, these measures assisted these nations in reducing case numbers and death rates. Some nations have removed the lockdown restrictions, and others intend to do so due to economic pressures (Bertuzzo et al. 2020; Dev and Sengupta 2020). However, once these limitations are relaxed, the epidemic's development may resume. As a result, it is critical to predict how the epidemic will proceed if the measures are introduced or withdrawn. Such forecasts can give useful information to grasp the present situation better and assist policymakers and health officials in developing suitable plans to govern the country. The problem, however, is generating forecasts for nations that are still in the early stages of the COVID-19 epidemic and have insufficient data to train an appropriate statistical model. As the corona cases started to be controlled, different countries removed lockdown to return to normal life as before COVID-19. Wuhan, China, is marking a year since it was placed under a 76-day lockdown that began on Jan 23, 2020. However, there is no exact ending date of lockdown because many countries have imposed a partial lockdown instead of a complete lockdown to control coronavirus cases. The region of Bavaria in Germany is imposing stricter rules, but the country is unlikely to return to full lockdown. India reopened the Taj Mahal. Only the USA is being pursued in these cases. At the end of January, China launched the world's biggest quarantine to contain the coronavirus, shutting down at least 16 cities. Wuhan's curfew was lifted on April 8. Despite the fact that Brazil's infection rate has surpassed Spain and Italy, Rio de Janeiro has reopened. Some citizens in Madrid are speaking out against localized lockdowns.

Manufacture, reining, distribution, and transportation are altogether fragments of the food supply chain, which associates a farming landscape to the user's table (Chen et al. 2020). The declarations of social exclusion initially caused people to flock to delivery centers, resulting in a lack of certain goods. However, the food supply has recovered, and it is one of the mechanisms that should be managed to guarantee food stability. One of FAO duties is to ensure that food supply chains do not get broken and strive to progress (Chen et al. 2020). Consequently, amid government constraints on labor migration in agricultural systems, the availability of basic needs is generally guaranteed, although with some problems. When it comes to imported or sold products, the situation is different; foreign commerce was disrupted as a result of border closures, but after protective measures were established to prevent the virus from spreading, exchange improved. This may be inevitable, depending on what governments do to prevent the virus from spreading. The social services which some nations, mostly in Western Europe, have in place to support millions of households and kids with little financial means are important to the food delivery structure. This supply chain is supported in several ways:

- Provision of food ration packs and other essentials (for example, Indonesia and Taiwan).

- Socioeconomic allowance is equal to the cost of daily needed food parcels (for example, Peru, Japan, and Singapore).

While, based on historical events of China in the COVID-19 outbreak, there is a massive influence on the cattle industry due to difficulty in obtaining livestock feed and, on the other hand, labor scarcity, food flows are minimally 
disturbed, ensuring global supply stability (Zhang 2020). The FAO Food Price Index (FFPI), an indicator of the remaining percentage of world charges of a collection of foodstuffs, measures the price elasticity of demand around the world. According to the FAO, the FFPI in February 2020 averaged 180.5 points, down to 1.9 points $(1.0 \%)$ from January, and marking the very first couple of weeks of decline following 4 months of raises. That is attributable to a dramatic decline in the exchange rate of soybean oil and a minor degree, meat, and grains, which helped to counter the continued increase in the cost of milk products and sugar.

Several governments' travel bans have hampered the distribution of chicken-breeding programs. If the immigration ban is extended, the International Poultry Council (IPC) has warned that breeding stock and hatching eggs will be unavailable (Vorotnikov 2020). Fish is an essential source of nutrition and calories for 3 million humans, accounting for more than $20 \%$ of protein intake (A, F. 2020). Because of hygienic steps (physical separation), insufficient input availability, and supply shortages, commercial fishing has been decreased in various parts of Africa, Asia, and Europe (FAO 2020). Owing to a shortage of grain and food, fishermen seem to be unable to market their stock, and fish farming activity is hampered. Since agriculture output is largely perishable, farmers are forced to preserve their unpurchased products for extended periods, resulting in lower food outcomes and better production costs (FAO 2020). COVID-19 has wreaked havoc on the availability of milk and dairy products. After a significant reduction in milk production and the closing of a milk manufacturing business, dairy farmers are allowed to liquidate milk and milk products. Dairy producers in the USA say that almost 4 million gallons of milk are dumped every day (Forstadt 2020). Most governments have achieved policies such as home detention, travel bans, and company closures to monitor the infection rate. Such travel restrictions had a huge effect on food delivery at all levels of the food supply chain (Figure 2).

Dairy products weighing the National Population Register (NPR) 2 billion have also been lost in Nepal, and processed foods with a share value of NPR 5 billion appear to be on the edge of degradation (Poudel et al. 2020). Farmworkers are experiencing a scarcity of agricultural products such as grain, fertilizer, and chemicals as a consequence of international trade disruptions. China is among the nation's top fertilizer producers and exporters. The world fertilizer trade has been seriously impacted by China's lockdown (Marlow 2020). Winter crops such as corn, sunflower, spring wheat, barley, soybean, and empty area vegetables have been impacted by the disease outbreak. In the Kharif season, India even needs 250 lakh quintals of seed (Singh 2020). As a result, if the pandemic continues, the sowing of Zaid and Kharif season crops will be hampered. As a result, import-dependent states are indeed particularly vulnerable to virus outbreaks (Cullen

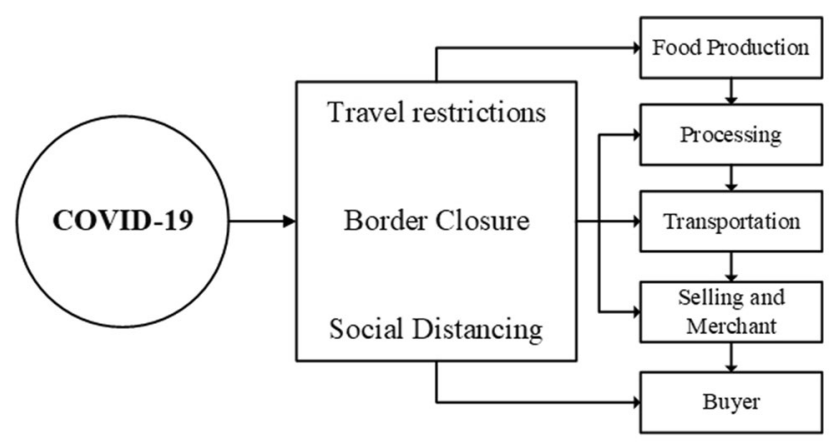

Prevention to control Pandemic

Food Supply Chain

Fig. 2 The figure shows that the COVID-19 affects every point of the food supply chain, with a significant impact on food transportation and delivery

2020). Workers' well-being and labor shortages have become major issues in the farming industry due to the increasing level of COVID-19 distribution. Jobs in low- and middle-income nations neglect adequate welfare and social security, and several irregular farmworkers are obligated to work regardless of the COVID-19 pandemic's self-isolation policy due to a shortage of savings or no savings. As a result, these workers are at a high risk of contracting the coronavirus (Monitor 2020). Around the globe, unemployment is increasing rapidly. COVID-19, according to the International Labor Organization (ILO), has impacted $81 \%$ of the world's workers (2.7 billion workers) due to complete or limited workplace closures (Poudel et al. 2020).

\section{Food demand}

Customers' craving and capacity to affordable prices for a definite item or variety at a certain period are stated as demand (Siche 2020). Due to anxiety and a reduction in customers buying aptitude, food production has deteriorated, though, if the epidemic persists too long, the condition may worsen due to a weakened economy and consumption reductions (Siche 2020). Leading to prohibition measures in China, which is a major producer globally and where the COVID-19 disease originated, his analysis demonstrates a rise in the set of users throughout the foodservice industry (A, F. 2020). In cases like this, where an infection spreads by communication, users favor mobile payment distribution systems. Many use aircraft for food distribution (Figure 3). Food consumption has been harmed as a result of lower wages and purchasing power. Frightened food supply and prices have been impacted as a result of consumer storage. The cost of the products, on the other hand, is determined by the nation and its disease outbreak control strategy. According to Siche, the prices of raw materials are likely to remain steady, although high-valued goods can experience price spikes (Siche 2020). In the current situation, animal protein intake has declined dramatically due to the erroneous view of animals as virus reservoirs. 


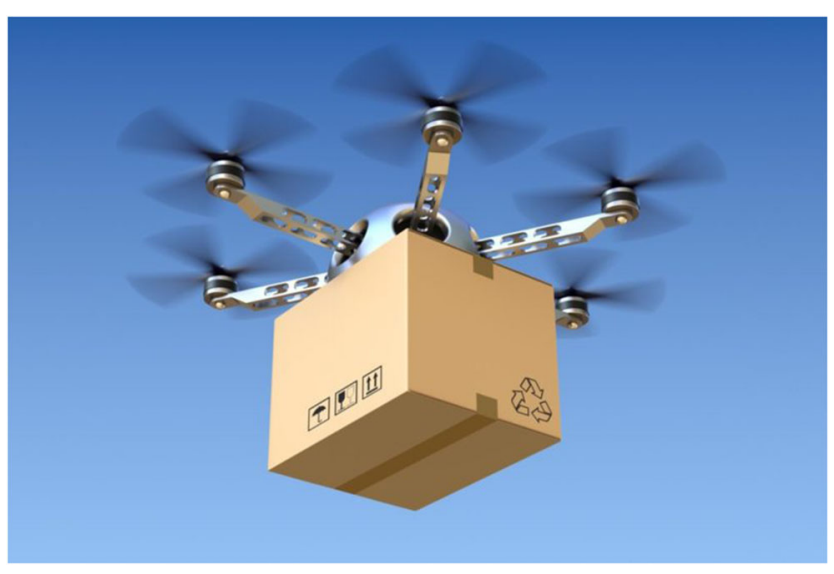

Fig. 3 Non-contact food delivery through drone system

\section{Food security}

Food nutrition refers to anyone having unlimited access to healthy food sufficient to improve their living conditions (Rosales and Mercado 2020). If immediate measures are not taken, a food shortage will loom, wreaking havoc on one of the neediest (Figure 4). The emphasis of the initiatives should be on maintaining the world's food chains operational and minimizing the pandemic's effects on the agricultural system. Brief emergencies are mitigated by welfare workers, who serve as shelters. Therefore, people who suffer from undernourishment and therefore do not eat sufficient dietary food to sustain a stable life, which numbers about 820 million individuals, have been the only disadvantaged group (A, F. 2020). This community of people could even withstand any disruption of their health and lives or nutrition that a COVID-19 outbreak could cause.

The effects may be extreme if the situation escalates in areas where certain residents migrate and where medical facilities are underdeveloped. Local agriculturalists are a further underprivileged group, as they may be incapable of working in the field or moving into the export industry for their harvests or buying grains and other important ingredients. Food protection generally refers to the constant supply and distribution of a reasonable amount of nutritional food. Food

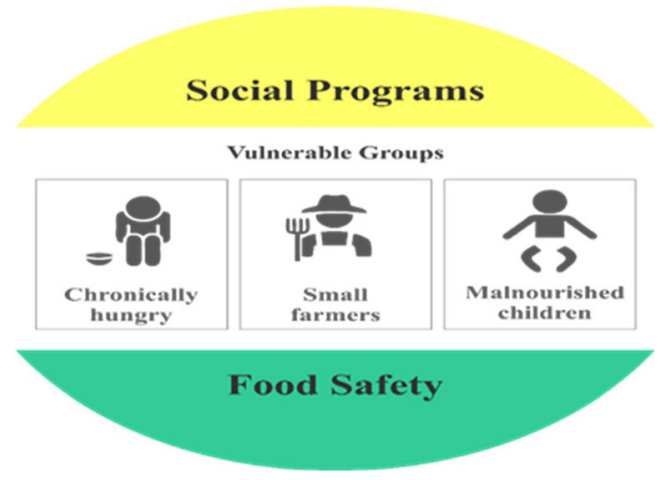

Fig. 4 Groups at the risk of food shortage (Siche 2020) insecurity may occur as a result of a decrease in foreign trade, as well as disruptions in food distribution and production. According to the FAO, small farmers and fishermen can have trouble exporting their products, resulting in a decline in their income and buying power. COVID-19 has increased food poverty, which would disproportionately affect the poorest populations of the country (A, F. 2020). Children with low households, who are mostly Hispanic, are indeed the third disadvantaged group, properly fed by food supported by social services; the pandemic's cessation of these programs endangers food supply, as well as the life of adolescents with little abilities to deal with pathogens (Siche). As a result, each nation must focus its efforts on maintaining social food services while still having the appropriate measures to prevent the virus from spreading.

\section{Impact of COVID-19 on school closure and education}

With the outbreak of COVID-19 worldwide, the authorities of different countries decided to close all educational institutes like schools, colleges, and universities in the direction of social distancing and to overcome the spread of this viral disease. The closure of educational institutes imposes bad effects on $80 \%$ of children's education. The empirical discussion is in progress concerning educational institute closure or opening, based on the spread of viral infection (Cohen and Kupferschmidt 2020). The education sector remains one of the worst-hit by the coronavirus outbreak. A pandemic is defined as an "outbreak of disease that occurs all over the world" (Adedoyin and Soykan 2020) and has an impact on a large population. The coronavirus was discovered in the last month of 2019 in a seafood market in Wuhan (China), a novel coronavirus (Huang et al. 2020).

The COVID-19 increases the gaps in education sectors or causes ore educational disruption. It has no boundaries and its effect is large and fast. Due to this pandemic, online learning has been introduced and more use of Internet technology for collecting materials for education purposes (Fry 2001). Before the outbreaks of COVID-19, educational institutions that had instilled the use of new technologies in their processes had a competitive benefit over those that had yet to implement the technology in their activities. Students needed to adapt to the current teaching and learning processes, and teachers were able to teach online. Students in areas where there were no relevant technologies and facilities to support online education faced an obstacle in making the transition to online education. Information technology was also a significant issue, especially for students in rural areas.

This is due to the fact that students and teachers in rural areas often lack the facilities and skills required to incorporate the online teaching-learning process. Many people lack the 
digital capabilities needed to incorporate online education. Technology continues to be a therapy for bridging developmental disparities caused by unplanned school closures during epidemics. Due to COVID-19, students and teachers or faculty members face more challenges and opportunities in the world battle to remove the pandemic. There are a variety of reasons for this, including restricted learning resources, prolonged research, specific training options, restricted wireless Internet, additional Internet bundle costs, education interruption, and, most importantly, no employment opportunities declared as a result of this disease outbreak. This study aims to look at the different obstacles that impeded the digital education system during this outbreak. The survey aims to look at the effects of corona disease on schooling.

\section{Mechanism of school closure}

With the closure of schools in the USA and Europe, two major solutions are being debated. The first is that shutting down schools increases the risk of food vulnerability. Research reveals that schools are not only education-providing places but are also a platform that supplies healthy food to ingest. Food insecurity will be increased with the closure of schools. It will influence the state of health and mental stability of students (Bitler and Seifoddini 2019; Schwartz and Rothbart 2020). A large number of children suffer from food insecurity. Eurostat stated that $5.5 \%$ of families with children in the UK and $6.6 \%$ in the European Union could not provide feed for fish or meat (Coleman-Jensen et al. 2014). Another mechanism is that the closure of schools also consists of non-school variables such as housing insecurity, health, and physiological emotions, and also many other factors by which expected education results cannot be achieved. During school vacations due to COVID-19, the difference in precise and learning abilities between children from inferior to developed socioeconomic origins also broadened (Alexander et al. 2007).

\section{Influence of COVID-19 on education}

The global school closures caused by the Coronavirus have had a devastating impact on the educational environment (Mustafa 2020). However, according to United Nations Educational, Scientific, and Cultural Organization (UNESCO) tracking, over half of the world's education system has been affected by worldwide closures of schools (Abari and Orunbon 2020). According to Voice of America (VOA) news, the widespread distribution and rate of academic damage caused by the coronavirus are unprecedented. If it continues, it could adversely affect access to quality education.

Unexpected school closures pose numerous challenges for students and significantly affect academic achievement and results (Figure 5). It is claimed that the institution's closing is contentious and that it would have ramifications for a considerable number of schools in terms of acquiring books. COVID-19's digital communication would not be able to eliminate face-to-face contact among students and instructors. Students' lives have been affected in many ways as a result of the COVID-19 disease outbreak, based not just on their degree and field of study but also on where they are in their courses. Making the transition from one stage of education to another, such as from university to tertiary education or from tertiary education to jobs, presents unique obstacles. They will be unable to regularly fulfill their national curriculum and assessments, but they will be separated from their peer circle nearly immediately in many instances. Learners who begin tertiary schooling during this year are unable to enroll in a later class for their year-end school tests (e.g., the International Baccalaureate), and those in the middle of their courses will be concerned before they have a good picture of how their classes and evaluation systems will be implemented following the disaster.

Numerous students in the COVID-19 cluster are concerned that they will face long-term drawbacks as they progress to the next stage of research or reach the labor market, relative to those who graduated "normally." Statements from colleges and universities that apply acceptance requirements "empathetically: will not always be reassuring. Although there would be clear differences in strategies for remote learning between basic (primary) school and higher education, the demands of skills-sector programs (Technical and Vocational Education and Training-TVET) need particular focus. Graduate students of such programs would play a critical role in the recovery of the economy. It is possible to include the specific learning they need in online courses, although it would necessitate special plans.

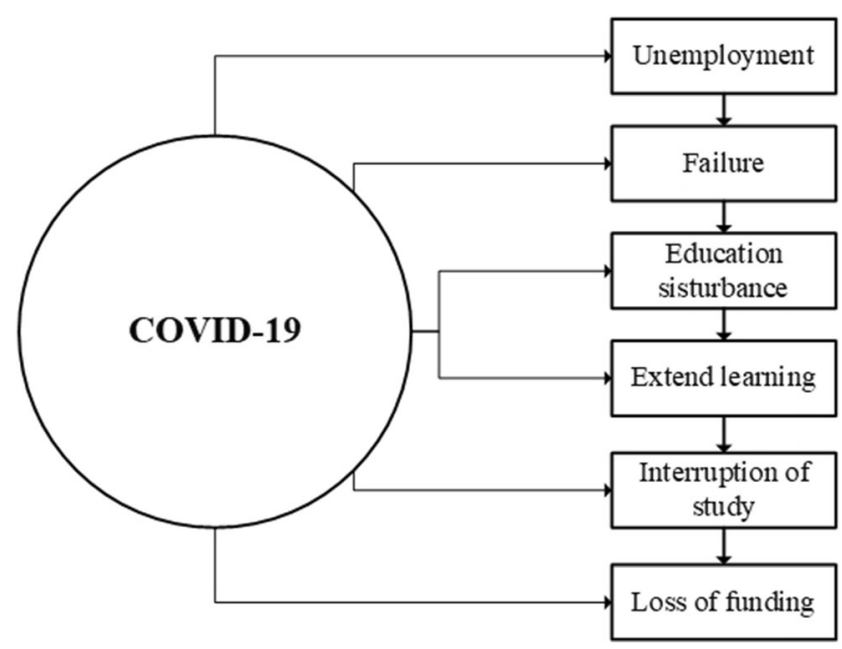

Fig. 5 Influence of COVID-19 on education 


\section{Effect of school closure due to COVID-19}

School closures can indeed be responsive (schools close after coronavirus infections are discovered among teachers, administrators, and family members) or preventive (colleges and universities close just before the disease ever hits the doors of schools and universities). The closure of schools due to the Coronavirus has created a new difficulty: shifting to digital and at-home instruction. Nigeria, Ghana, Senegal, South Africa, China, Kazakhstan, Ethiopia, Honduras, India, Japan, Iran, USA, France, Spain, Italy, North and South Korea, Lebanon, Vietnam, Thailand, Germany, Pakistan, and South Korea are only a handful of the countries that have closed schools due to COVID-19. Because of the increase in COVID-19 cases, schools in infected areas closed and in other uninfected places open with limitations by following SOP's (Figure 6). School closures have high psychological, cultural, and financial consequences, and the changes they create affect people from all walks of life, but they have a disproportionately negative effect on poor members of the community (Abari and Orunbon 2020).

According to UNESCO, harmful effects due to COVID-19 by school closure are the following:

- Education disruptions

- Limited access to Internet communication channels

- Added stress on the education and its program

- Maintain the distance from others

If a more durable coronavirus cure is not identified promptly and the infection spreads, the damage caused by COVID-19 in the educational sector could last further than predicted. According to VOA News (2020), UNESCO Director-General Andrey Azoulayals cautioned that "the global size and pace of the educational damage caused by coronavirus are unprecedented and, if sustained, could endanger the right to education." Unscheduled school closures will, without reason, create significant issues for teachers, administrators, families, and society as a whole. The US Centers for Disease Control and Prevention (CDC) is also concerned about the

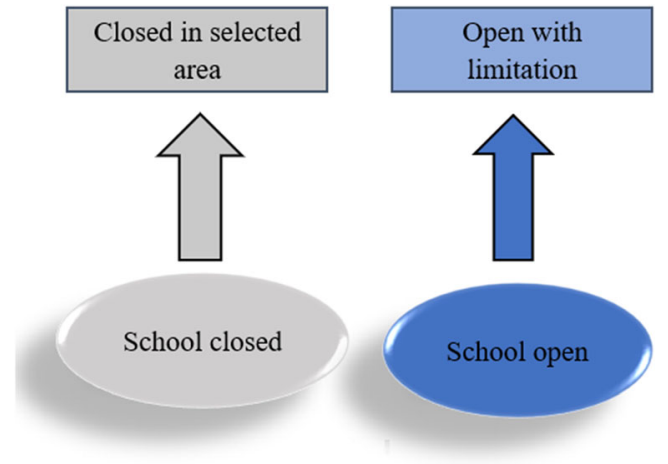

Fig. 6 School closure all over the world because of COVID-19 consequences of school closing. "Longer closures can result in more students congregating outside of schools," according to the CDC. According to Quentin (2014), school closures are divisive, and they may have far-reaching consequences for a significant number of children in obtaining college. It can have an impact on the standard of teaching and learning as well as academic performance, especially for students with special needs or learning disabilities who need more physical affection and direction from teachers. Though technology can help mitigate some of the effects of school closing, it cannot eliminate the importance of students and teachers interacting face to face. Furthermore, many students lack access to comprehensive software, making it more difficult to maximize the benefits of digital learning throughout school closures. According to computer analysis and empirical study of adaptive school closures in previous pandemics, it reduces the total percentage of cases in the population by $25 \%$. It delays the duration of the disease outbreak by a week or two. In contrast, constructive school closures throughout epidemics appear to be one of the most effective strategies that can be used to reduce implacability. Social isolation is difficult to enforce in school due to the architecture of the school and the scale of their classes. COVID-19 has had and continues to have a detrimental impact on research programs due to university closures.

\section{Concept of online education}

In the past half-century, the delivery of schooling has improved at all levels, but the COVID-19 epidemic has disrupted this mechanism in all countries where the virus has spread. The governments of these countries order their organizations to discontinue physical classes in favor of a modern school system based on online classes. Since most policymakers were playing catch-up to COVID-19's explosive spread, organizations had no time to plan for an online teaching system. Preparations should be used, if possible:

- Ensuring that students were given the books and other materials they required to prepare at home.

- Tying up loose ends, for example, finalizing test results and analyses. Several public-school teachers in the northern hemisphere were anticipating year-end test grades for submitting students' assignments to higher education. Teachers' forecasts may have differed depending on whether they were made before or after the official interruption of these tests, causing uncertainty for both themselves and their pupils.

- Preparation and planning for staff: protection plans; job separation between departments; structures for staff to communicate with one another for shared guidance; and short and easy information on teaching methods that are already common. Many organizations had planned to 
increase their use of technology in the classroom, but the spread of COVID-19 forced them to make improvements in a matter of days rather than months or years.

Institutions must improve their ability to instruct digitally in the same way they improve their opportunity to teach, motivate, and facilitate communication between students and parents. Now is not the time to set in place complex structural arrangements for online courses that were supposed to take months or years to execute. The adage "if a job needs doing, it's probably conducted poorly" holds. Teachers should use what they have already learned. It is more critical to think all of your time on educating pupils than it is to attempt to pick up new teaching methods. For those that are adapted to teaching in actual classes, the most significant change is to use asynchronous instruction. The learners do not have to interact concurrently in certain areas of studying and teaching. Asynchronous working allows teachers to be more flexible when creating instructional resources and allows students to balance home and school obligations. Digital formats are ideal for asynchronous learning.

Teachers do not have to provide content at a certain time: it can be uploaded online for on-demand exposure, and pupils can connect with it at their own time using online resources, blogs, and e-mail. Teachers can monitor student engagement regularly and schedule online appointments for students who have specific needs or concerns. Teachers and students have more breathing space in an asynchronous digital school. Similarly, brief video lectures (5-10 $\mathrm{min})$ are normally more effective and easier to plan. Future Learn, a company that offers large-enrollment online classes, has optimized remote learning methods that combine usability and effectiveness. The digital education infrastructure is almost sufficient to compensate for the lack of learning time. This warning aims to advise students, institute heads, and administrators to monitor the educational consequences of such a catastrophe. Teachers' training methods have changed as a result of the increased use of technology in education, which has changed their standard coaching approach. As a result, mentors and motivation factors have fewer opportunities to motivate pupils to study and grow (Onyema et al. 2019). Some of these technology tools are the following:

- Whatsapp.com

- Zoom (zoom.us)

- Google Hangouts (hangouts.google.com)

- Stanford online (onlinestanford.edu)

- Skype.com

- Youtube.com

- Google classroom

- Easyclass.com

- Google meets

- Software meet and so on
In the curriculum, the use of such tools improves the learning environment for students. The knowledge of these techniques increases the confidence of students and their interest in the study. The global appetite for online education grew as a result of the COVID-19 epidemic. Technology has the power to make education accessible from everywhere, even the comfort of one's own home. If the world struggles to control COVID-19 or other potential outbreaks, schools, universities, educators, and students can increasingly depend on digital technology platforms. Technology is critical for connectivity and contact when students and teachers are isolated, quarantined, or locked down as a result of health issues or other incidents.

\section{Difficulties of studying at home}

However, due to the closure of classrooms due to COVID-19, a digital learning framework has been implemented. While this method of teaching is new, it is not as easily learned as studying in a classroom. To take an online class, a digital education framework needs a convenient location at home as well as quick Internet connections. In an online class, a large number of students do not pay attention. The digital revolution in the learning process brought with it plenty of technological issues and mindset shifts. During COVID-19, 70\% of learners participated in e-learning. Students must overcome stress, anxiety, inadequate Internet access, and an adverse research atmosphere at home to join online classes. In short, the COVID-19 epidemic wreaked havoc on the educational system because neither teachers nor students were well-prepared for e-learning. For both students and guardians, this is a stressful moment. Anxiety is exacerbated by the uncertainty of when everything will change to "usual." Even when organizations make the necessary adjustments to teaching in new ways, they should all prioritize encouraging students and parents by direct contact. Without adequate guidance from reviewing authorities and organizations on the plans for implementing canceled exams and changing admissions processes, many teachers and social workers will be forced to offer this validation. Organizations should keep students and parents informed of these issues regularly. Teachers and administrators could be more effective than parents at calming the fears of students living in poverty. On the other hand, all have access to support lines and services outside of the education system specializing in social and psychiatric issues. Various jurisdictions developed "open" institutions fifty years ago to equalize opportunities by expanding higher education via distance learning. Unfortunately, the current pressure to keep students in school by making hasty transfers to online learning may have the opposite result. Institutions and school programs must make extra efforts to assist children who have unsympathetic families who live in homes that are not conducive to learning. When COVID-19 confines households to 
their homes, parents may be concerned about their financial prospects, making studying at home difficult, particularly for children with low motivation. The dilemma is exacerbated by the fact that such homes often neglect the facilities and accessibility that wealthier households take for granted.

\section{Difficulties of conducting examinations during COVID-19}

Most institutions decided to avoid any in-person interaction and close their institutions completely during the early phases of the epidemic when the origin of the coronavirus was still unclear. Many children throughout the world connect the conclusion of the school year with high-stakes exams (Wilcha 2020). These are frequently used to assess or certify pupils as they go through the educational system. Exams often play a significant equality responsibility to minimize the impacts of favoritism and increasing access to educational opportunities for students from underserved families. With school closures and prohibitions on weekly meetings due to the coronavirus, numerous solutions and precautions are being implemented for students' examinations. There are three primary ways to consider (Liberman et al. 2020).

\section{Cancelation of examinations}

All written exams for junior high school students in the 10th grade (final year) and students in all 3 years of secondary school have been canceled in Norway. Exams account for $20 \%$ of the final grade, but course participation accounts for $80 \%$ of the final mark; therefore, the cancelation is unlikely to have a significant impact. In the Indian state of Uttar Pradesh, children in grades 1 through 8 will be promoted to the following grade without having to take an examination. The SAT is frequently utilized in the university admissions process in the USA, and it is given in person at institutions. The SAT on May 2, 2020, has been delayed, and the exam on June 6 is being reconsidered. As a result, several institutions in the USA are changing their admission standards to make such examinations optional. Students will be granted a Diploma or a Program Certificate "based on the student's schoolwork and the preexisting assessment competence, discipline, and quality control already integrated into the programs," rather than the Cambridge International tests (Liberman et al. 2020).

\section{Rescheduling examinations}

Students who planned to take the West African Senior School Certificate Examination (WASSCE) in May or June 2020 should be aware that the test has been stopped in their countries and will be rescheduled whenever the health situation improves. The Caribbean Examination Council (CXC), which includes 16 West Indian nations and territories, has moved its high school exams from May to July 2020. Despite the fact that the Czech Republic has broadcast preparation for school-leaving tests on television, there are currently plans to reschedule the exams. Hong Kong's Diploma of Secondary Education (DSE) test has been prolonged by a month (to April 24, 2020). In Ireland, talks are continuing to extend the Leaving Cert (the post-primary education terminal test that is used to choose students for further study and work), which was scheduled for June 2020, including the beginning of the next academic year at universities and colleges. Exams for higher education in India have also been postponed, and the administration is trying to modify the test timetable as well as the academic calendar. The GaoKao university admission tests in China, which are taken by almost 10 million students each year, have been pushed back one month to July 7 and 8, 2020. State examinations in Colombia have been delayed as rescheduling possibilities are investigated (Liberman et al. 2020).

\section{Exams are still being held in a modified manner}

Some examinations are still in progress. Sixth-year medical school students in the UK have just completed their examinations online for the first time. Even though the examination was "open book," it was probably difficult to score well by browsing for material online without understanding the subject topic. Students had $3 \mathrm{~h}$ to complete 150 questions. Advanced Placement (AP) tests, which are used to gain a graduate degree in the USA and assess students' mastery of knowledge and abilities in a given topic, will be conducted online this year in a free-response style, and with resources offered by the school and teachers online. In the Caribbean, the CXC high school examinations will be administered in modified online and offline modes, with multiple choice and school-based evaluations, used to calculate final marks. Secondary school-leaving examinations in Germany will be held under stringent hygiene and distance guidelines. Examinations have already happened, have been extended by several weeks, or will occur on time, depending on the country (Liberman et al. 2020).

\section{Difficulties of online examinations}

Some colleges have chosen to conduct most of their tests online to prevent a person to person contact. Imperial College London's 280 sixth-year medicine students were successfully graded via two online examinations in March. "To the best of our knowledge, this is the first digital 'open book' test administered online for final-year students," says Dr. Amir Sam, Imperial's head of undergraduate medicine. Universities worldwide have followed the following since then, although they have encountered a number of obstacles along the road (Wilcha 2020). 
- One of the most difficult elements of administering remote examinations is ensuring that the Internet or other resources do not aid pupils.

- When students take examinations without an invigilator present, it may be simpler for them to seek answers somewhere or to talk about the process with each other.

- Each test will have its own set of regulations, but it will be more difficult to guarantee that pupils obey the guidelines when the examination is performed distantly.

- Universities employ companies like ProctorU to improve test performance by providing the technologies necessary to evaluate fraudulent activities during exams.

- Many undergraduates, meanwhile, have expressed privacy concerns about exam software designed to prevent cheating.

- Students at the University of Sydney were left "uneasy" after a distant exam in which they were told to expose their working space via web camera, provide confidential info, and be told that "any disturbance or movement you make will be videotaped, evaluated, and processed for two years," according to the Sydney Morning Herald.

- Other concerns with online examinations include ensuring that students have a good-enough Internet connection to participate in the exam and taking into consideration each student's time zone throughout the planning phase (Wilcha 2020).

\section{Influence of COVID-19 on the world's economy}

Coronavirus is a global threat, and policymakers around the world are doing all they can to combat it. The coronavirus epidemic, like past pandemics, is mostly a public health issue, but it is still, and gradually, an economic threat. It is anticipated that prohibiting economic activity by closing the market, i.e., imposing a lockdown, will prevent the spread of the virus. Apart from the prospect of achieving herd immunity, no other intervention is expected to be available to control the disease's course (Camera, et al., 2021). Apart from its grave implications for human life, the novel coronavirus strain (COVID-19) can dramatically delay not only the Chinese but also the world's economy (Magraw 2017). There are three distinct sources to consider when it comes to economic surprises, two of which are observable. The first is simply medical shocks: jobs on their code of practice are not contributing to economic output. The second consideration is the financial burden of public and private isolation policies, such as school and plant closures, transport bans, and quarantines. The third is a phrase that simply means "all of our hearts" (org Book 2020). However, its effect is much too great.
The epidemic has wreaked havoc on the tourist industry, affecting manufacturing and competitiveness, suppliers, financial prices, and economic consequences among countries. Companies are losing money, factories in China are shutting down, and millions of people are trapped at home. Since the coronavirus has disrupted financial activities, it is important to investigate the virus' financial implications in depth. Coronavirus is wreaking havoc on certain industries, including transportation, hotels, and foodservice. To combat the transmission of the epidemic, major companies are encouraging their workers to operate at home. However, working from home is not possible in any industry, and some employers require employees to take unpaid leave. The COVID-19 epidemic would affect economic activity across several sources. The majority of COVID-19's economic consequences would come from "non-pharmaceutical interventions (NPIs)" or "infection aversion practices" used to prevent disease. The state imposes restrictions on some kinds of events, businesses, and institutions take preventive steps to prevent pollution, and individuals limit their trips to the market and other social activities (Figure 7) (Evans and Over 2020; Hevia and Neumeyer 2020).

\section{COVID 19's economic impact on the manufacturing sector}

Manufacturing will help achieve global development targets by providing healthier and affordable goods, improved job opportunities, reduced unemployment, and a better lifestyle. The link between a productive and profitable sector and the economy is clear and significant, especially when it comes to jobs and industries that are interconnected (Feyisa 2020). Industrial trade accounts for $25.44 \%$ of the total world economy, according to a 2017 survey. Manufacturing would be one of the main aspects of the economy adversely impacted by COVID-19's emerging global disaster (Feyisa 2020). The nominal exchange rate of the 10 leading economies accounts for about $66 \%$ of global gross domestic product (GDP), while the top 20 economies account for nearly 79\%. However, according to the United States National Bureau of Statistics data, 8 of the top ten global economies are in the top 10 exporting countries. The industrial purchasing major index (PMI) is representative of the current industrial market situation. The highlight of PMI is a number ranging from zero to one hundred. As opposed to the earlier month, a PMI of over $50 \%$ indicates improvement. A PMI score of less than 50 indicates a reduction, while a score of 50 shows no progress. Due to COVID-19, almost all countries, except China and India, have a reading $<50$ in March, with China showing an increase over previous months. 
Fig. 7 Networks of the possible economic impact of COVID-19 (Feyisa 2020)

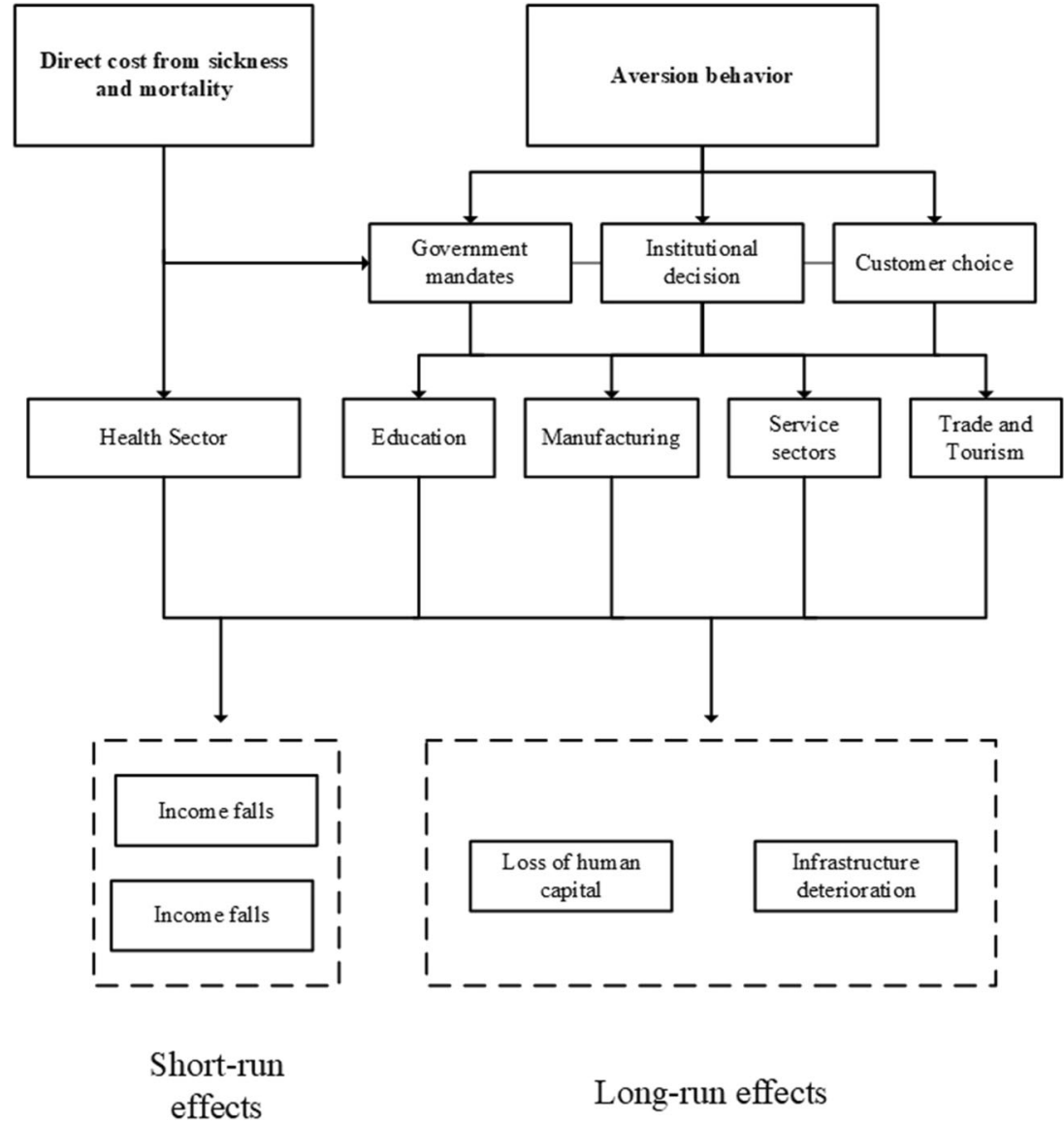

\section{Impact of COVID-19 on the service sector}

The services sector has risen to become the wealthiest and most important segment of the economy, representing an increasing share of GDP, investment, and jobs. Many programs with essential social roles, such as health, banking, electricity, transportation, and telephone, are needed to meet the Sustainable Development Goals (Feyisa 2020). According to figures from 2017, the service sector accounts for $65.03 \%$ of global GDP. Because of the world's resistance to COVID-19, workers in the service industry that rely on customer-provider connections are likely to experience a significant reduction. Restaurant staff, as well as those employed in caregiving, shopping, and transportation, are at significant risk of losing their jobs (Kochhar and Barroso 2020). The PMI for services is a predictor of the current trajectory of economic conditions in the services industry, as well as an indicator of the sector's economic health. The news PMI is a number ranging from zero to one hundred. As compared to the previous month, a PMI of over 50\% indicates expansion. A PMI score of less than 50 indicates a reduction, while a score of 50 indicates no improvement. The greater the transition, the farther away from 50 you are. In our situation, COVID-19 has resulted in a reading of less than 50 in almost all nations, except China, in March 2020. We can see that the service sector's economic growth is slowing on the shoulders of the world's top nine economies, but it is strengthening moderately in China.

\section{COVID-19 influence on the transportation and tourism}

The World Travel \& Tourism Council (WTTC) report, which was focused on data from 185 countries and 25 regions, found that the tourism and travel industry accounted for $10.4 \%$ of global GDP and 319 million workers, or $10 \%$ of overall employment in 2018, with a direct share in GDP of USD 2,750.7 billion (3.2\% of GDP) (Škare et al. 2021). To stop the transmission of the coronavirus, countries all over the globe have assumed cautions to people to discourage unsafe travel. Simultaneously, COVID-19 affects the airline industry, which is closely linked to tourism and other sectors of the economy. COVID-19 is expected to have the following effect on scheduled international passenger traffic in the first half of 2020, as opposed to the standard (as originally planned): Airlines have reduced the number of seats they are offering from 41 to $51 \%$. This could result in a drop in passenger numbers from 443 million to 561 million. The future decline of overall operating income for airlines is estimated to be between USD 98 and USD 124 billion, and if the present rate of loss extends until September 2020, airlines will lose more than USD 35 billion 
global net revenue per month in the third quarter of 2020 (Bureau 2020). As well, several states have postponed the visas of travelers from coronavirus-affected states. People are hesitant to fly because of the fearful climate. As a consequence of these factors, the transport business is on the threshold of collapsing. As per the Airline, the aerospace industry could keep losing approximately 63 billion and 112 billion dollars, with a cumulative impact of 112 billion dollars. The valuation of airport stocks has fallen by $25 \%$. In February-March, Chinese flights are canceled by the majority of their commercial airlines. Singapore Airlines' estimated ability has been cut by $10.3 \%$. Lawmakers must take precautions to prevent the virus' effects on the aviation industry (Riley 2020). Although most governments have imposed regional and global immigration restrictions, this significantly impacts the hospitality industry sectors, which depend heavily on tourism. Restaurant chains in the USA, such as Le Bernardino, Michael, and Grand Central Medical Organization's cafe, have temporarily closed. According to the Regional Tourism Board, hospitality shutdowns will result in the loss of approximately 50 million employment opportunities. Clients are staying home due to lockdowns. At the provincial scale, tourism is a significant source of income for many economies in developing Asia - in markets like Palau and the Maldives, foreign tourism revenues contribute for more than $40 \%$ of GDP, and overall travel and tourism (including domestic tourism) reaches $10 \%$ of GDP in nearly half of Asian Development Bank (ABD) participating countries (Abiad et al. 2020).

The tourism industry is more prone than any other to the COVID-19 outbreak and its related financial pressures, since it is focused on human activity. The tourism industry is now one of the hardest hits by COVID-19, which has affected both production and consumption for travel. According to United Nations World Trade Organization (UNWTO) projections, as of April 7, 2020, global foreign tourists could decrease by 20 $30 \%$ in 2020 , down from a projected rise of 3 to $4 \%$ in early January 2020 . This may reduce $\$ 30$ to $\$ 50$ billion in foreign tourist spending (Feyisa 2020). Large restaurant chains, including Hilton, Marriott, and Transcontinental, have seen their stock values drop by around $16 \%$. The Walt Disney Company estimates that the Coronavirus would cost it $\$ 175$ million (Creswell 2020).

\section{COVID-19's economic effect on trade}

International commerce has a major impact on each nation's economy. It enables the public's requirements to be met and promotes sustainable growth (Makhmutova and Mustafin 2017). Together, trade and hospitality account for about $18 \%$ of the world economy. Even though trade allowed COVID-19 to progress from outbreak to disease outbreak and infect more people worldwide, COVID-19's economic impact cannot be avoided. Since the COVID-19 outbreak has disrupted usual economic growth across the globe, international trading growth is projected to drop by 13 to $32 \%$ in 2020. According to WTO economists, the downturn would most likely surpass the trading recession affected by the global economic crisis of 2008-2009 (W. T. Organization, 2020). The impact of coronavirus disease on trade can be seen in Table 3.

\section{Effect of COVID-19 on stock exchanges}

Since the coronavirus disease outbreak has badly affected almost all of the public stocks, most international stock markets have reportedly reached a market crash (Cheung 2020). The world stock value has shrunk by $30 \%$. Throughout the quarter of March, financial markets around the world experienced strong instability and ambiguity. Coronavirus has led the stock market in the USA to plunge to its lowest level since 1987. Because of the decline in supply and improvement in market demand, the COVID-19 pandemic has had a major impact on GDP. Furthermore, the pandemic would aggravate the problems if banks struggle to satisfy the firms' borrowing requirements due to a drastic drop in demand. As a result, financial world markets would eventually crash (Khan et al. 2020). The World Economic Forum has promised $\$ 14$ billion in assistance to fight it. It will provide financial aid to participating nations to develop their healthcare facilities and facilities and recognize the contagious disease at the given timeframe (Seery et al. 2020).

\section{COVID-19's economic impact on the education sector}

In a variety of platforms and several different ways, education contributes greatly to economic development and health (Feyisa 2020). As an essential factor of a nation's human resources, education enhances personal workforce productivity and aids economies in moving up the supply chain above daily labor or basic manufacturing processes (Feyisa 2020). As the planet grapples with the scope and seriousness of the

Table 3 Projections from the World Economic Outlook (WEO)

\begin{tabular}{llll}
\hline Trade volume & \multicolumn{3}{l}{ Actual calculations } \\
\cline { 2 - 4 } & $\mathbf{2 0 1 9}$ & $\mathbf{2 0 2 0}$ & $\mathbf{2 0 2 1}$ \\
\hline Volume of global exchange (goods and services) & 0.9 & -11.0 & 8.4 \\
Importing & 1.5 & -11.5 & 7.5 \\
Developed economies & -0.8 & -8.5 & 9.1 \\
Economics of developing countries & & & \\
Exporting & 1.2 & -12.8 & 7.4 \\
Developed economies & 0.8 & -9.6 & 11.0 \\
Economics of developing countries & & & \\
\hline
\end{tabular}


COVID-19 pandemic, non-pharmaceutical initiatives (NPIs) such as school closures are taking precedence over education (Feyisa 2020). One hundred twenty countries have closed schools as of March 1, 2020, affecting almost a billion children around the world who have had their schools closed for varying amounts of time (Bank 2020). To stop the spread of the COVID-19 pandemic, most governments around the world have temporarily shut down education institutes. About $91 \%$ of the world's school students are required to sit at home due to school closures, with varying degrees of E-learning opportunity. Several other countries have introduced localized closures that would affect millions of more students. COVID-19, according to IIEP experts, would have a substantial economic effect on the school system across two channels: the lack of education expenditure for the length of the recession, as well as the associated increased costs and the anticipated reduction in the academic sector's potential financial capital (Feyisa 2020).

\section{Conclusion}

The COVID-19 pandemic has had a great influence on civilization's actions and practices. It has a substantial effect on education, agriculture, and the economic sectors of the world. The face-to-face education system has been replaced by an online teaching method. This digital system of education can never replace the physical education system. The asynchronous education system is beneficial to overcome the loss of student's studies. This outbreak messes up the food supply chain. Owing to mobility constraints, limited earning potential, and a superior influence on the neediest demographic groups, food ingestion and security are expressively impacted. If the number of cases of contagion rises, countries will take more stringent steps to stop the virus from spreading, affecting the world economic system. COVID-19 harmed tourism, trade, stock exchange, and the manufacturing industry and caused a contraction in the world's economy. We should strictly follow SOP's to improve our agriculture, education, economy, and other ways of normal life.

Acknowledgements The listed authors are thankful to their representative universities for providing the literature services.

\section{Availability of data and materials Not applicable}

Author contribution Conception and design of study: Mehvish Mumtaz, Nazim Hussain; material preparation, search, and collection of relevant articles/reviews: Zulqarnain Baqar, Saima Anwar; writing-review and editing: Mehvish Mumtaz, Muhammad Bilal. All authors have read and approved the final manuscript.

Funding Not applicable

\section{Declarations}

Ethics approval Not applicable

Consent to participate Not applicable

Consent of publication Not applicable

Competing interests Not applicable

\section{References}

A, F. (2020) COVID-19 pandemic-impact on food and agriculture Q1: will Covid-19 have negative impacts on global food security. Rome, Italy, FAO

Abari AO, Orunbon NO (2020) Building bridges and walls: education and COVID-19 in Nigeria. Research Journal in Comparative Education 1(1):39-52

Abiad A, Arao M, Dagli S, Ferrarini B, Noy I, Osewe P, . . Park DRP (2020). The economic impact of the COVID-19 outbreak on developing Asia, 10

Adedoyin OB, Soykan E (2020) Covid-19 pandemic and online learning: the challenges and opportunities. Interact Learn Environ:1-13

Alexander KL, Entwisle DR, Olson LS (2007) Lasting consequences of the summer learning gap. Am Sociol Rev 72(2):167-180

Bank W (2020) The COVID-19 pandemic: shocks to education and policy responses: World Bank

Barichello R (2020) The COVID-19 pandemic: anticipating its effects on Canada's agricultural trade. Canadian Journal of Agricultural Economics/Revue canadienne d'agroeconomie 68(2):219-224

Benvenuto D, Giovanetti M, Ciccozzi A, Spoto S, Angeletti S, Ciccozzi M (2020) The 2019-new coronavirus epidemic: evidence for virus evolution. J Med Virol 92(4):455-459

Bertuzzo E, Mari L, Pasetto D, Miccoli S, Casagrandi R, Gatto M, Rinaldo A (2020) The geography of COVID-19 spread in Italy and implications for the relaxation of confinement measures. Nat Commun 11(1):1-11

Bitler MP, Seifoddini A (2019) Health impacts of food assistance: evidence from the United States. Ann Rev Resour Econ 11:261-287

Bureau AT (2020) Effects of novel coronavirus (COVID-19) on civil aviation: economic impact analysis. International Civil Aviation Organization (ICAO), Montréal, Canada

Burgui D (2020) Coronavirus: how action against hunger is responding to the pandemic. Available in: https://www. actionagainsthunger. org/ story/coronavirus-how-action-against-hunger-respondingpandemic

Chen S, Brahma S, Mackay J, Cao C, Aliakbarian B (2020) The role of smart packaging system in food supply chain. J Food Sci 85(3):517-525

Cheung B (2020) Yahoo is now a part of Verizon media

Cohen, J., \& Kupferschmidt, K. (2020). Countries test tactics in 'war'against COVID-19: American Association for the Advancement of Science.

Coleman-Jensen A, Gregory C, Singh A (2014) Household food security in the United States in 2013. USDA-ERS Economic Research Report 173

Creswell, J. (2020). What happens in Vegas if no one stays in Vegas.

Cullen MT (2020) Coronavirus food supply chain under strain what to do. What to do 39

Dev SM, Sengupta R (2020) Covid-19: impact on the Indian economy. Indira Gandhi Institute of Development Research, Mumbai April

Du N, Yang X-X, Yang L, Zeng Y-H, Zou S-M, Bo H et al (2009) Review on the etiological property of 1957 Asian flu virus (H2N2). Bing du xue bao= Chinese Journal of Virology 25:12-16

Evans D, Over M (2020) The economic impact of COVID-19 in low-and middle-income countries. Center For Global Development Blog 
FAO (2020) How is COVID-19 affecting the fisheries and aquaculture food systems

Farmer P (2019) Ebola, the Spanish flu, and the memory of disease. Crit Inq 46(1):56-70

Feyisa HL (2020) The World Economy at COVID-19 quarantine: contemporary review. Int J Econ, Finance and Management Sciences 8 (2):63-74

Forstadt J (2020) Dairy industry upended by COVID-19. WSKG-NPR, Vestal, NY, USA

Frank MacFarlane Burnet S, Burnet FM, Burnet M, White DO. (1972) Natural history of infectious disease: CUP Archive

Fry K (2001) E-learning markets and providers: some issues and prospects. Education+ Training

Hanashima M, Tomobe K i (2012) Urbanization, industrialization, and mortality in modern Japan: a spatio-temporal perspective. Ann GIS 18(1):57-70

He H, Harris L (2020) The impact of Covid-19 pandemic on corporate social responsibility and marketing philosophy. J Bus Res 116:176-182

Hevia C, Neumeyer A (2020) A conceptual framework for analyzing the economic impact of COVID-19 and its policy implications. UNDP LAC COVID-19 Policy Documents Series, 1, 29

Hey J (2020) Coronavirus: measuring the market impact. URL: http:// www. fruitnet. com/asiafruit/article/181021/coronavirus-measuring-themarket-impact (дата обращения 16.05. 2020)

Hrastinski S (2008) Asynchronous and synchronous e-learning. Educ Q 31(4):51-55

Huang C, Wang Y, Li X, Ren L, Zhao J, Hu Y et al (2020) Clinical features of patients infected with 2019 novel coronavirus in Wuhan, China. Lancet 395(10223):497-506

Khan K, ZHAO H, Zhang H, Yang H, Shah MH, Jahanger A (2020) The impact of COVID-19 pandemic on stock markets: an empirical analysis of world major stock indices. The Journal of Asian Finance, Economics, and Business 7(7):463-474

Kochhar R, Barroso A (2020) Young workers likely to be hard hit as COVID-19 strikes a blow to restaurants and other service sector jobs. Pew Research Center, March, 27

Liberman J, Levin V, Luna-Bazaldua D, Harnisch M (2020) High-stakes school exams during COVID-19 (Coronavirus): what is the best approach? World Bank Blogs.

Lippi G, Plebani M (2020) Laboratory abnormalities in patients with COVID-2019 infection. Clin Chem Lab Med (CCLM) 58(7): $1131-1134$

Lv M, Luo X, Estill J, Liu Y, Ren M, Wang J et al (2020) Coronavirus disease (COVID-19): a scoping review. Eurosurveillance 25(15): 2000125

Magraw K (2017) I. 32 United Nations Conference on Trade and Development (UNCTAD) Elgar Encyclopedia of International Economic Law (pp. 73-76): Edward Elgar Publishing

Makhmutova DI, Mustafin AN (2017) Impact of international trade on economic growth. International journal of scientific study 5(6):140-144

Marlow S (2020) COVID-19: effects on the Fertilizer Industry. IHS Market 24(3):2-6

Monitor I (2020) COVID-19 and the world of work. Updated estimates and analysis

Mustafa N (2020) Impact of the 2019-20 coronavirus pandemic on education. International Journal of Health Preferences Research:1-12

Onyema EM, Ogechukwu U, Anthonia ECD (2019) Potentials of mobile technologies in enhancing the effectiveness of inquiry-based learning approach. International Journal of Education (IJE) 2(01)

org Book AV. (2020) Economics in the time of COVID-19

Organization WH (2013) HIV/AIDS: global situation and trends. Global Health Observatory.

Organization WH (2020) WHO director-general's opening remarks at the media briefing on COVID-19-11 March 2020: Geneva, Switzerland
Organization WT (2020) Trade set to plunge as COVID-19 pandemic upends global economy: World Trade Organization Geneeva

Pan A, Liu L, Wang C, Guo H, Hao X, Wang Q et al (2020) Association of public health interventions with the epidemiology of the COVID19 outbreak in Wuhan, China. Jama 323(19):1915-1923

Peak CM, Childs LM, Grad YH, Buckee CO (2017) Comparing nonpharmaceutical interventions for containing emerging epidemics. Proc Natl Acad Sci 114(15):4023-4028

Poudel PB, Poudel MR, Gautam A, Phuyal S, Tiwari CK, Bashyal N, Bashyal S (2020) COVID-19 and its global impact on food and agriculture. Journal of Biology and Today's World 9(5):221

Prem K, Liu Y, Russell TW, Kucharski AJ, Eggo RM, Davies N et al (2020) The effect of control strategies to reduce social mixing on outcomes of the COVID-19 epidemic in Wuhan, China: a modelling study. Lancet Public Health 5(5):e261-e270

Pretty JN, Morison JI, Hine RE (2003) Reducing food poverty by increasing agricultural sustainability in developing countries. Agric Ecosyst Environ 95(1):217-234

Riley C (2020) This is a crisis.'Airlines face $\$ 113$ billion hit from the coronavirus

Rosales G, Mercado W (2020) Efecto de los cambios en el precio de los alimentos sobre el consumo de la quinua y la seguridad alimentaria rural en el Perú. Scientia Agropecuaria 11(1):83-93

Schwartz AE, Rothbart MW (2020) Let them eat lunch: the impact of universal free meals on student performance. Journal of Policy Analysis and Management 39(2):376-410

Seery E, Marriott A, Malouf Bous K, Shadwick R (2020) From catastrophe to catalyst: can the World Bank make COVID-19 a turning point for building universal and fair public healthcare systems?

Siche R (2020) What is the impact of COVID-19 disease on agriculture? Scientia Agropecuaria 11(1):3-6

Siddiquei MI, Khan W (2020) Economic implications of coronavirus. J Public Aff 20(4):e2169

Singh I (2020) Agriculture in the time of COVID-19. The Hindu, Business Line

Škare M, Soriano DR, Porada-Rochoń M (2021) Impact of COVID-19 on the travel and tourism industry. Technol Forecast Soc Chang 163: 120469

Steffens I (2020) A hundred days into the coronavirus disease (COVID19) pandemic. Eurosurveillance 25(14):2000550

Team EE (2020) Note from the editors: World Health Organization declares novel coronavirus (2019-nCoV) sixth public health emergency of international concern. Eurosurveillance 25(5):200131e

Trevino LK (1986) Ethical decision making in organizations: a personsituation interactionist model. Acad Manag Rev 11(3):601-617

Vorotnikov V (2020) Coronavirus could disrupt poultry production. Poultry World

Wang T, Du Z, Zhu F, Cao Z, An Y, Gao Y, Jiang B (2020) Comorbidities and multi-organ injuries in the treatment of COVID-19. Lancet 395(10228):e52

WHO (2020) Coronavirus disease (COVID-2019) situation reports

Wilcha R-J (2020) Effectiveness of virtual medical teaching during the COVID-19 crisis: systematic review. JMIR Medical Education 6(2): e20963

Wu Z, McGoogan JM (2020) Characteristics of and important lessons from the coronavirus disease 2019 (COVID-19) outbreak in China: summary of a report of 72314 cases from the Chinese Center for Disease Control and Prevention. Jama 323(13):1239-1242

Zhang X (2020) Chinese livestock farms struggle under COVID-19 restrictions. IFPRI book chapters:84-85

Publisher's note Springer Nature remains neutral with regard to jurisdictional claims in published maps and institutional affiliations. 